\title{
Clues to an Evolutionary Mystery: The Genes for T-Toxin, Enabler of the Devastating 1970 Southern Corn Leaf Blight Epidemic, Are Present in Ancestral Species, Suggesting an Ancient Origin
}

\author{
Bradford J. Condon, ${ }^{1}$ Candace Elliott, ${ }^{2}$ Jonathan B. González, ${ }^{1}$ Sung Hwan Yun, ${ }^{3}$ Yasunori Akagi, ${ }^{4}$ \\ Tyr Wiesner-Hanks, ${ }^{5}$ Motochiro Kodama, ${ }^{4}$ and B. Gillian Turgeon ${ }^{1,+}$ \\ ${ }^{1}$ Section of Plant Pathology \& Plant-Microbe Biology, School of Integrative Plant Science, 334 Plant Science Building, Cornell \\ University, Ithaca, NY 14853, U.S.A.; ${ }^{2}$ School of Biosciences, Building 122 Rm 121, The University of Melbourne, Parkville 3010 \\ VIC Australia; ${ }^{3}$ Department of Medical Biotechnology, Soonchunhyang University, Asan 31538, South Korea; ${ }^{4}$ The United \\ Graduate School of Agricultural Sciences, Tottori University, 4-101 Koyama-Minami, Tottori 680-8553, Japan; and ${ }^{5}$ Section of \\ Plant Breeding, School of Integrative Plant Science, 240 Emerson Hall, Cornell University, Ithaca, NY 14853
}

Accepted 21 May 2018.

The Southern corn leaf blight (SCLB) epidemic of $1970 \mathrm{dev}$ astated fields of T-cytoplasm corn planted in monoculture throughout the eastern United States. The epidemic was driven by race $T$, a previously unseen race of Cochliobolus heterostrophus. A second fungus, Phyllosticta zeae-maydis, with the same biological specificity, appeared coincidentally. Race $T$ produces T-toxin, while Phyllosticta zeae-maydis produces PMtoxin, both host-selective polyketide toxins necessary for supervirulence. The present abundance of genome sequences offers an opportunity to tackle the evolutionary origins of T- and PM- toxin biosynthetic genes, previously thought unique to these species. Using the $C$. heterostrophus genes as probes, we identified orthologs in six additional Dothideomycete and three Eurotiomycete species. In stark contrast to the genetically fragmented race $T$ Tox 1 locus that encodes these genes, all newly found Tox 1 -like genes in other species reside at a single collinear locus. This compact arrangement, phylogenetic analyses, comparisons of Tox 1 protein tree topology to a species tree, and Toxl gene characteristics suggest that the locus is ancient and that some species, including $C$. heterostrophus, gained Toxl by horizontal gene transfer. $C$. heterostrophus and Phyllosticta zeae-maydis did not exchange Tox1 DNA at the time of the SCLB epidemic, but how they acquired Tox1 remains uncertain. The presence of additional genes in ToxI-like clusters of other species, although not in C. heterostrophus and

Bradford J. Condon, Candace Elliott, and Jonathan B. González contributed equally to this work.

${ }^{\dagger}$ Corresponding author: B. Gillian Turgeon: E-mail: bgt1@cornell.edu

Funding: Bradford J. Condon was supported in part by a Cornell University Presidential Fellowship. Jonathan B. González was supported by a National Science Foundation graduate research fellowship. Sung Hwan Yun was supported by Basic Science Research Program through the National Research Foundation of Korea (NRF) funded by the Ministry of Science and Information, Communication \& Technology (NRF-2017R1A2B4011541).

*The $\boldsymbol{e}$-Xtra logo stands for "electronic extra" and indicates that 14 supplementary figures and five supplementary tables are published online.

@ 2018 The American Phytopathological Society
Phyllosticta zeae-maydis, suggests that the metabolites produced differ from T- and PM-toxin.

Cochliobolus heterostrophus (Bipolaris maydis), causal agent of Southern corn leaf blight (SCLB), was first described as a mild pathogen of maize in 1925 (Drechsler 1925). In 1970, however, a new, highly virulent race (race $\mathrm{T}$ ) appeared in Florida and swept up the east coast of the United States in a single growing season, destroying more than $15 \%$ of the maize crop. The affected maize carried Texas male sterile cytoplasm (T-cms), planted because the male sterility trait facilitated cross pollination and concomitant hybrid vigor (Levings 1993). Unfortunately, as later discovered, the maize mitochondrial protein (Urf13) conferring this beneficial breeding trait co-confers (Dewey et al. 1988; Levings 1990) sensitivity to T-toxin, a family of polyketide (C35-C45-linear poly- $\beta$-ketols) host selective toxins (HST) produced by race $\mathrm{T}$ of the fungus (Daly 1982). The origin of race $\mathrm{T}$ and its ability to produce T-toxin, a metabolite not identified in any other fungus, including earlier known $C$. heterostrophus race $\mathrm{O}$, have remained a mystery (Inderbitzin et al. 2010; Turgeon and Baker 2007; Turgeon and Lu 2000; Yang et al. 1996).

Intriguingly, a second maize pathogen, Phyllosticta zeae-maydis (Didymella zeae-maydis or Peyronellaea zeae-maydis [Arny and Nelson 1971; Aveskamp et al. 2010], hereafter D. zeae-maydis), appeared coincidentally with $C$. heterostrophus race T, leading to speculation that it might be the source of genes for toxin production, because it also produces a family of polyketide toxins (PM-toxin, C33-C35-linear poly- $\beta$-ketols) with identical biological specificity (maize with Urf13) to T-toxin (Yoder and Mukunya 1972). However, when a polyketide synthase $(P K S)$ gene required for PM-toxin production was identified (Yun et al. 1998), it was only about $60 \%$ identical to one of the $P K S$ s required for T-toxin production. This divergence ruled out the possibility that one of these fungi donated toxin-associated DNA to the other at the time of the epidemic.

The better-studied C. heterostrophus Toxl locus is genetically and physically complex (Turgeon and Baker 2007). Although segregation ratios in progeny of crosses between naturally occurring race $\mathrm{T}$ and race $\mathrm{O}$ strains indicated early on that Tox 1 was a single genetic locus, this proved to be incorrect (Kodama 
et al. 1999). Molecular genetic analyses have revealed that T-toxin biosynthesis requires at least nine genes (encoding two PKSs, a decarboxylase, several types of reductase, and a protein of unknown function) mapping to two loci (ToxlA, ToxlB) on two different chromosomes that are reciprocally translocated in race $\mathrm{T}$ with respect to their race $\mathrm{O}$ counterparts (Baker et al. 2006; Inderbitzin et al. 2010; Rose et al. 2002; Yang et al. 1994, 1996). None of the known Toxl genes is found in race $\mathrm{O}$ or any other Cochliobolus species. The reciprocal translocation breakpoints that segregate genetically with ToxlA and ToxlB are associated with $1.2 \mathrm{Mb}$ of highly $\mathrm{A}+\mathrm{T}$ rich, repeated DNA (Tzeng et al. 1992), however only approximately $40 \mathrm{~kb}$ is connected by function to Toxl. Although nine Toxl genes were known prior to the present study, whether or not this was the complete locus was uncertain. Prior to the present study, only three genes, one encoding a PKS and two encoding reductases had been associated with D. zeae-maydis PM-toxin production (Yun 1998).

Rapid advancement of comparative genomic resources combined with an increased understanding of evolution and diversity of genes encoding PKS enzymes have brought us closer to understanding race $\mathrm{T}$ evolution. It should be noted however, that PKS-encoding genes are fast-evolving, discontinuously distributed, and highly recombinogenic (Bushley and Turgeon 2010; Bushley et al. 2008; Condon et al. 2013); tracing their evolutionary origins and distinguishing between horizontal gene transfer (HGT) and a history of discontinuous evolution mediated by loss, gain, and recombination are difficult (Condon et al. 2013; Kroken et al. 2003).

Taking advantage of the bounty of sequenced genomes, we conducted Blast and phylogenetic studies with the nine known C. heterostrophus Toxl proteins as queries. Remarkably, we found orthologs of most Toxl genes arranged, side by side, in the genomes of three Eurotiomycete species, namely, Penicillium raistrickii, a soil fungus, $P$. nalgiovense, first isolated from cheese, and P. brevicompactum, a saprobe; three dicot Dothideomycete pathogens, Leptosphaeria maculans, Ascochyta rabiei, and Corynespora cassiicola; two aquatic Dothideomycetes, Clohesyomyces aquaticus and Lindgomyces ingoldianus; and the Dothideomycete mycoparasite Ampelomyces quisqualis. We also sequenced one strain of D. zeae-maydis and found all Toxl genes on four contigs. The tight gene clusters in fungi not known to produce HSTs are a cipher for the structures of the C. heterostrophus and D. zeae-maydis disjointed Tox1 loci, allowing a more informed evolutionary hypothesis about their evolutionary origin.

\section{RESULTS}

\section{C. heterostrophus Tox1 orthologs are found in other fungi.}

Blast searches with the $C$. heterostrophus Pks1 protein identified the previously known $D$. zeae-maydis Pks1 orthologous protein (Inderbitzin et al. 2010) plus newly detected ortho$\operatorname{logs}$ in Leptosphaeria maculans, Corynespora cassiicola, Ascochyta rabiei, Lindgomyces ingoldianus, Ampelomyces quisqualis, Clohesyomyces aquaticus, $P$. raistrickii, $P$. nalgiovense, and $P$. brevicompactum as top hits (Supplementary Table S1). Blast searches with the $C$. heterostrophus Pks2 protein identified, for the first time, Pks2 orthologs in D. zeae-maydis and in all other species named above. Queries with the remaining known C. heterostrophus Tox 1 proteins, revealed the entire suite in all, with the following exceptions: REDI, encoding one of three reductases at $C$. heterostrophus Toxl is missing from all species except $D$. zeae-maydis, the only other species known to produce an HST. The gene complement in both $P$. brevicompactum isolates is incomplete with only ToxlA-like orthologs present (Fig. 1). Similarly, Clohesyomyces aquaticus lacks RED1, DECl, and either RED2 or RED3 (discussed below). D. zeae-maydis has two
OXI (oxidoreductase) genes $(O X I 1, O X I 2)$ whereas all other taxa have a single gene.

\section{The Tox1-like genes in additional species are in a single cluster.}

Notably, candidate Toxl-like genes in the additional species are in clusters ranging in size from 30 to $40 \mathrm{~kb}$, which is comparable to the sum of all known $C$. heterostrophus Toxl genes (Fig. 1). This linear arrangement is markedly different from the race T Toxl structure. As mentioned, C. heterostrophus Toxl is two loci, ToxlA and ToxlB, on different chromosomes; five known genes, cosegregating genetically with Tox $1 A$, are physically located on three scaffolds (Joint Genome Institute [JGI] scaffolds S74, S83, S102), while four genes, cosegregating with Tox 1B, are on one scaffold (JGI scaffold S82) (Baker et al. 2006; Inderbitzin et al. 2010, Rose et al. 2002, Yang et al. 1994, 1996).

Relative gene position is largely but imperfectly conserved in most clusters (Fig. 1). Particularly, the positions of TOX10 (not identified previously at $C$. heterostrophus Toxl, as described below) and DECl are reversed in Leptosphaeria maculans relative to Ampelomyces quisqualis, Ascochyta rabiei, the three strains of Corynespora cassiicola, and Lindgomyces ingoldianus. In Ampelomyces quisqualis, PKS1 orientation is reversed relative to TOX10 in the other species mentioned above but matches that of $C$. heterostrophus. In Penicillium species and D. zeae-maydis, TOX10 is adjacent to LAM1 rather than PKS1. In $P$. brevicompactum, an esterase is between TOX9 and PKSI. Toxl-like genes in Clohesyomyces aquaticus are on two different scaffolds, PKS1 is truncated at the $5^{\prime}$ end, and only one $R E D 2 / 3$ gene (described below) is on these scaffolds. Genome database searches failed to identify the missing genes. Gene order is as in Lindgomyces ingoldianus, however, whether this is a single cluster cannot be determined at this time.

\section{New Tox1 genes?}

As noted, genes not known previously to be part of C. heterostrophus Toxl were identified in most clusters. These genes fell into two categories. In the first category is a gene at C. heterostrophus Tox1. In the second, are genes in other Tox1like clusters but not in $C$. heterostrophus. The gene in the first category, exemplified by Leptosphaeria maculans JGI protein ID 11519 , encodes a protein without any similarity to currently predicted functional domains. An ortholog is found in $C$. heterostrophus adjacent to PKSI (Fig. 1), and, like all known Toxl genes, is unique to race $\mathrm{T}$ (not found in race $\mathrm{O}$ ) (Inderbitzin et al. 2010). Deletion yielded a strain that was unable to make T-toxin (Fig. 2A, left) and was reduced in virulence to T-cms corn (Fig. 2B, left), thus, it is clearly a member of the Tox 1 complement (and because its function is unknown, was named TOX10, for the tenth Toxl gene discovered).

In the second category are two genes, an $A B C$ gene, encoding a predicted transporter and a NAD oxidoreductase-encoding gene $(O X R)$ are in most clusters but not those of $C$. heterostrophus or D. zeae-maydis (Fig. 1). Phylogenetic analyses further support the observation that the $A B C$ (Supplementary Fig. S1) and $O X R$ (Supplementary Fig. S2) genes are not in these genomes and, thus, are not required for toxin biosynthesis, yet they sit in the middle of most Toxl-like clusters. These findings lead us to speculate that the nontoxin-producing species synthesize a T-toxin-like secondary metabolite and that the $\mathrm{ABC}$ and OXR proteins play a role in structural and functional differences between that molecule and T- or PM-toxin.

Finally, we examined the boundaries of the Toxl-like clusters in all genomes to determine whether flanking genes should be considered part of Toxl or offered clues to C. heterostrophus race $\mathrm{T}$ Toxl evolution, or both. Where it could be examined (i.e., where Toxl was not flanked by repeats or at scaffold ends), 
Cochliobolus heterostrophus $\mathrm{C} 4$ race $\mathrm{T}$

Tox1A

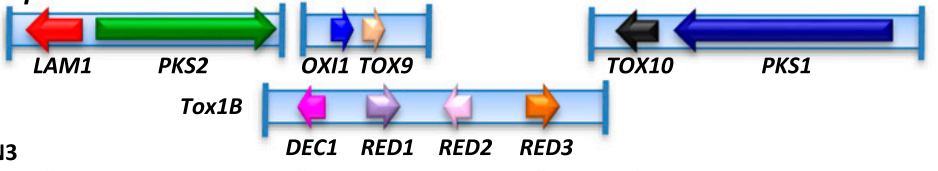

Leptosphaeria maculans JN3

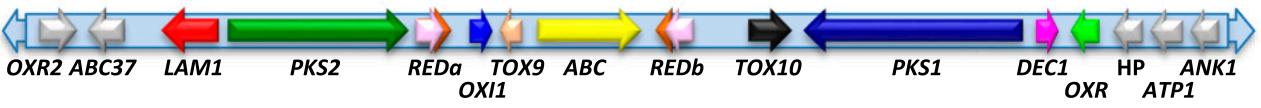

Ampelomyces quisqualis HMLAC05119 v1.0

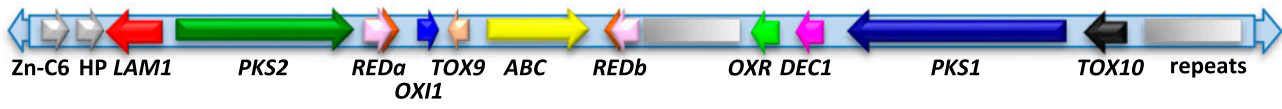

Ascochyta rabiei ArDII

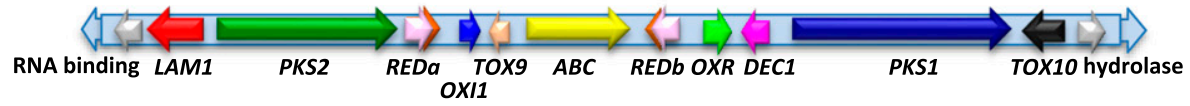

Corynespora cassiicola MAFF306176 (cucumber)

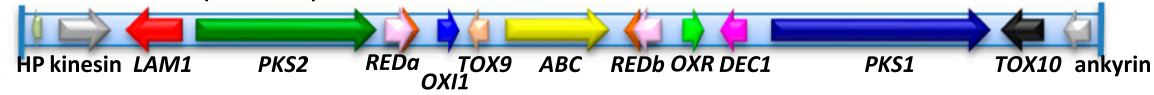

Corynespora cassiicola MAFF242452 (tomato)

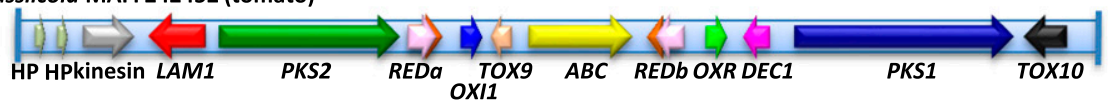

Corynespora cassiicola CCP v1.0 (rubber)

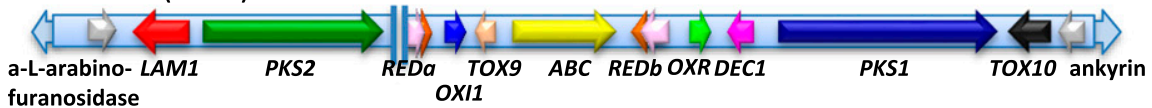

Lindgomyces ingoldianus ATCC 200398 v1.0

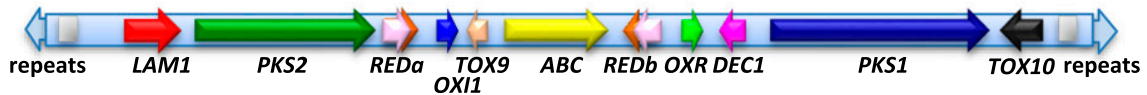

Clohesyomyces aquaticus CBS 115471
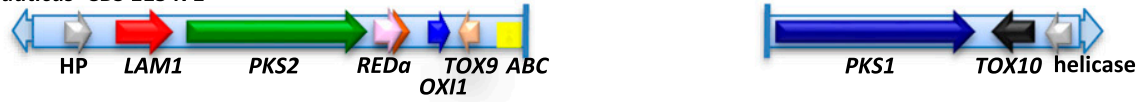

Penicillium raistrickii ATCC 10490 v1.0

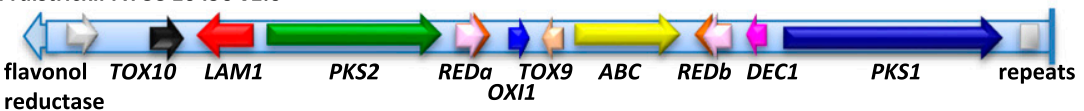

$$
\text { reductase }
$$

Penicillium nalgiovense FM193

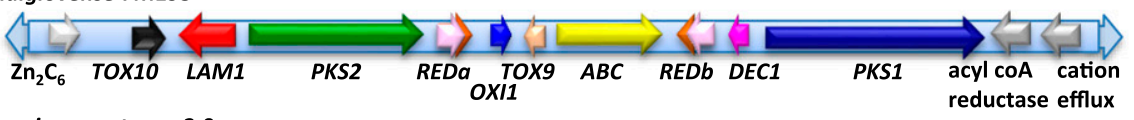

Penicillium brevicompactum v2.0

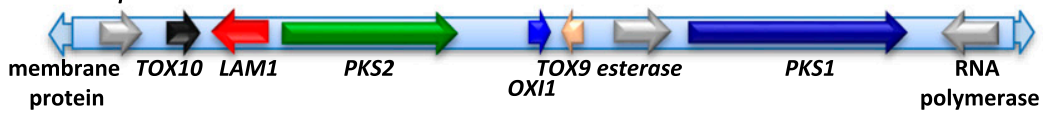

Penicillium brevicompactum AgRF18 v1.0

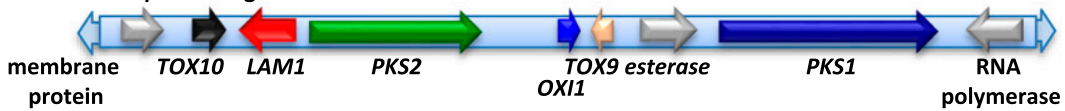

Didymella zeae-maydis 3018
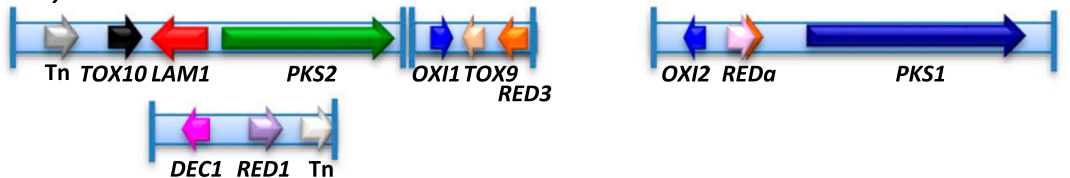

Fig. 1. Comparison of Toxl loci in Cochliobolus heterostrophus race T and other fungi. C. heterostrophus Toxl-associated genes are found on four scaffolds at two unlinked loci (ToxlA, ToxlB). In other fungi, Toxl-like genes are clustered collinearly. Arrows indicate direction of transcription. Gene nomenclature follows that of $C$. heterostrophus race T (Inderbitzin et al. 2010). Gene synteny is largely, although not perfectly, conserved. Penicillium brevicompactum lacks Tox1B. Genes encoded: PKS1, PKS2 (polyketide synthases), LAM1 (3-hydroxyacyl-CoA dehydrogenase), OXI1 (NADP binding short chain dehydrogenase/reductase with broad range of substrate specificities), TOX9, TOX10 (predicted but unknown proteins), DEC1 (acetoacetate decarboxylase), RED1 (NAD dependent oxidoreductase), RED2, RED3 (predicted secreted NADP binding short chain dehydrogenase/reductases. Most clusters, except Tox1 in $C$. heterostrophus and Didymella zeae-maydis, include an $A B C$ gene encoding a predicted Abc transporter and an $O X R$ gene encoding a predicted NADP-binding, zincbinding oxidoreductase. Genes flanking the clusters are shown as white arrows. Vertical thick lines indicate scaffold ends or end of available sequence. Thick arrows at the end of clusters indicate the scaffold continues. HP = hypothetical protein, $\mathrm{Tn}=$ transposon. 
flanking genes varied by species, thus, we have no evidence for including additional genes as part of Toxl (Fig. 1). A central dilemma in understanding Toxl has been the confounding 1.2 $\mathrm{Mb}$ of DNA not found in race $\mathrm{O}$ that resides at the breakpoints of the reciprocal translocation associated with race $\mathrm{T}$ Toxl chromosomes (Tzeng 1990) and the small fraction of this DNA associated with Toxl. The single collinear and compact loci in additional species suggest that all genes required for T-toxin production may be in hand. We consider it likely that additional coding sequences are infrequent in the $1.2 \mathrm{Mb}$ of DNA mapping to the breakpoints. In support of this, earlier restriction fragment length polymorphism mapping indicated that $50 \%$ of all probes mapping within $4 \mathrm{cM}$ of Toxl are repetitive, in contrast to only $4 \%$ repetitive probes mapping elsewhere (Chang and Bronson 1996; Tzeng 1990). This is consistent with our inability to connect the four race T Toxl scaffolds, as all ends contain highly repeated sequences (Inderbitzin et al. 2010).

The inventory of known Toxl genes was found on four separate D. zeae-maydis scaffolds (Fig. 1). Three genes on Scaffold 1066 (PKS1, REDa, and OXI2) were identified previously (named PKS1, RED1, RED2, respectively) (Yun 1998). Disruption resulted in strains that were unable to make PM-toxin and reduced in virulence, i.e., pks 1 mutants (Yun et al. 1998) and reda and oxi2 mutants (Fig. 2A and B). As with C. heterostrophus, highly repetitive $\mathrm{A}+\mathrm{T}$ rich sequences surrounding the genes make it difficult to connect scaffolds; at this point, we do not know if PM-toxin Toxl is a single locus or multiple loci as in race $\mathrm{T}$.

To date, nine species carrying Toxl-like orthologs in compact clusters have been identified. The shattered locus in
C. heterostrophus was likely produced by one or more subsequent recombination events. The less parsimonious explanation would be that the two C. heterostrophus loci (Tox1A and Tox $1 B$ ) were rearranged, independently at various evolutionary times, to form single linear arrays in the additional species. We therefore infer that the single locus is the ancestral one. We consider it likely that a modification to the ancestral linear organization also occurred in D. zeae-maydis, given that most Toxl genes are surrounded by repeats or transposable elements (Yun 1998).

\section{Phylogenetic analysis of Tox1 genes.}

To trace evolutionary history of Toxl, we queried genome databases with $C$. heterostrophus Tox 1 proteins and constructed trees with approximately 100 top blast hits (Supplementary Figs. S3, S4, S5, S6, S7, S8, S9, and S10). C. heterostrophus Pks1 and Pks2 and all corresponding orthologs formed independent, highly-supported clades (Fig. 3). Delitschia winteri and Talaromyces stipitatus Pks1 proteins grouped sister to these proteins with robust support, as reported earlier (Condon 2013; Inderbitzin et al. 2010; Kroken et al. 2003). No additional Toxllike orthologs can be found in Talaromyces stipitatus. The Delitschia winteri genome sequence is not available, thus the question of whether or not additional Toxl-like genes are present cannot be addressed by genome query. Similarly, Botryosphaeria dothidea protein 293115 grouped with high support sister to the Pks2 clade, however, there is no compelling evidence for additional Toxl-like orthologs. Most strikingly, $P$. raistrickii, $P$. nalgiovense, and $P$. brevicompactum orthologs were nested within the Dothideomycete-rich clades. This

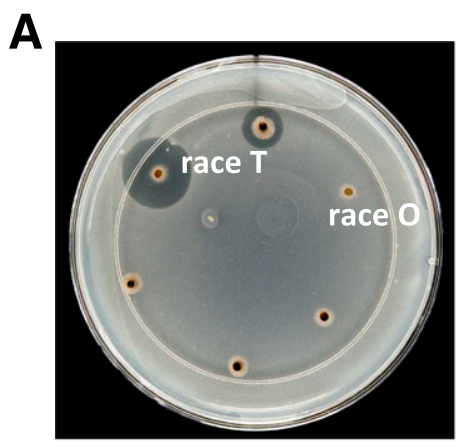

Ch tox10

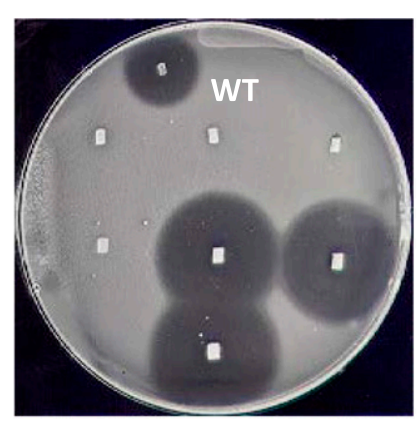

Dzm pks1

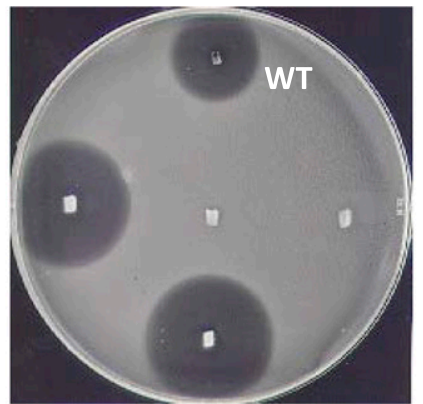

Dzm reda

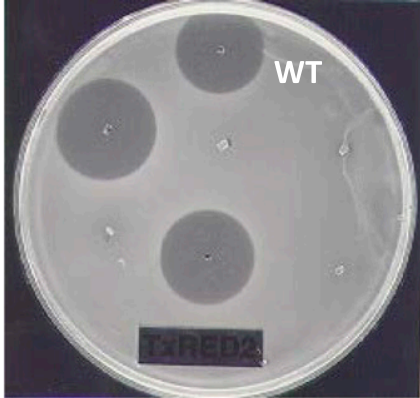

Dzm oxi2
B

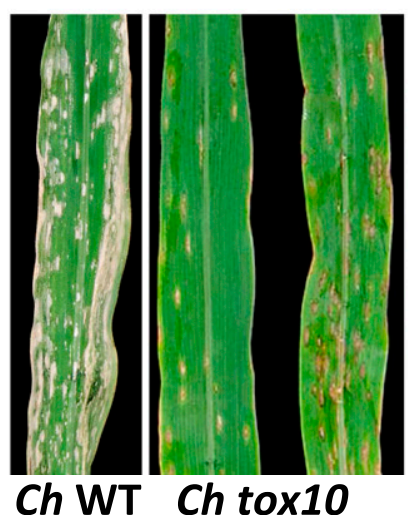

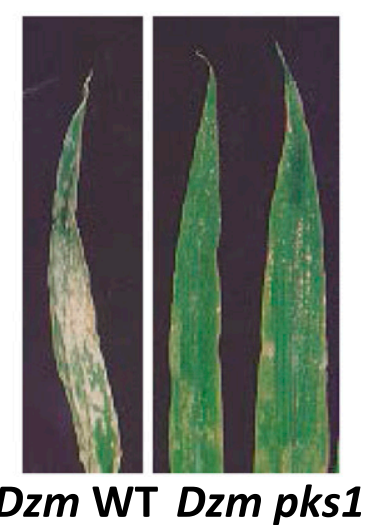

Fig. 2. Assay of mutants for toxin activity. Plates were spread with T-toxin- and PM-toxin-sensitive Escherichia coli cells and mycelial plugs to be tested were placed mycelium side down on the lawn of E. coli cells. A, From left: wild type (WT) Tox ${ }^{+}$Cochliobolus heterostrophus race T (halos), race O (no halo) controls, and tox 10 mutants (no halos); Didymella zeae-maydis WT Tox (top of plates, halo), pks1, reda, and oxi2 mutants. Of the latter, those with halos represent ectopic integrations, those lacking halos sustained disruptions of the PKS1 KS domain (second from left), REDa (second from right), or OXI2 (right) B, WT and mutants inoculated on Texas male sterile cytoplasm maize T. Left, C. heterostrophus WT and tox10. Right, D. zeae-maydis WT and pksl mutant. Toxin symptoms $=$ gray spreading lesions and leaf wilting. Note reduction in symptoms with mutants. 
suggests that they or a common ancestor may have acquired the genes from a Dothideomycete.

Similarly, Tox1A proteins Tox10, Lam1, Oxi1, and Tox9 grouped in well-supported clades. A protein from the Dothideomycete Periconia macrospinosa (ID 721783) was nested within the Lam1 group; however, no additional Tox1 proteins were found in the genome. Of the Tox $1 B$ proteins, all Dec1 proteins clustered with 0.88 support. However, this clade bifurcates into two groups; $C$. heterostrophus and D. zeae-maydis are in one group and the rest in a separate group, likely reflecting differences in Dec1 function in building the known HSTs and one or more unknown products of the compact clusters.

C. heterostrophus and D. zeae-maydis are the only species in the cohort that include Red1. These proteins grouped together in a well-supported clade with a Red1-like protein (ID 174379) of the Dothideomycete Phyllosticta citriasiana, for which there is no compelling evidence for additional Tox 1 orthologs. C. heterostrophus Red 2 and Red3 orthologs cluster together with high support, as previously noted (Inderbitzin et al. 2010), making it difficult to determine whether reductases in other species correspond to RED2 or RED3. D. zeae-maydis $\operatorname{Red} 3$ clusters with $C$. heterostrophus Red3. For simplicity, we have termed orthologs in other species as Reda (if they cluster with C. heterostrophus Red2 and Red3) and as Redb (if sister to C. heterostrophus Red 2 and Red3) in these trees. Note that, as with the Pks1 and Pks2 phylogenies, all Penicillium species Tox 1 orthologs are nested within Dothideomycete clusters.

\section{Evaluation of phylogenetic congruence} between species and Tox1 protein trees.

In an additional approach to evaluate evolutionary history, we built individual Tox 1 protein trees as well as a tree of species-specific concatenated Tox 1 proteins (Tox 1 tree) and evaluated congruence between these trees and a tree constructed using conserved protein sequences (as a proxy for the whole genome) in species harboring Tox1 (species tree) (Fig. 4). $\operatorname{Red} 2 / 3(\operatorname{Reda} / \mathrm{b})$ proteins were analyzed together and a Red1 tree was not constructed. As in the large trees, Penicillium species nested within Dothideomycetes. This suggests independent HGT into these species or into an Eurotiomycete ancestor before speciation. We favor the first of these, since regions flanking Toxl differ in the three species (Fig. 1). How $P$. brevicompactum lost Tox $1 B$ and acquired an intervening esterase is unresolved. The species tree, by comparison, showed
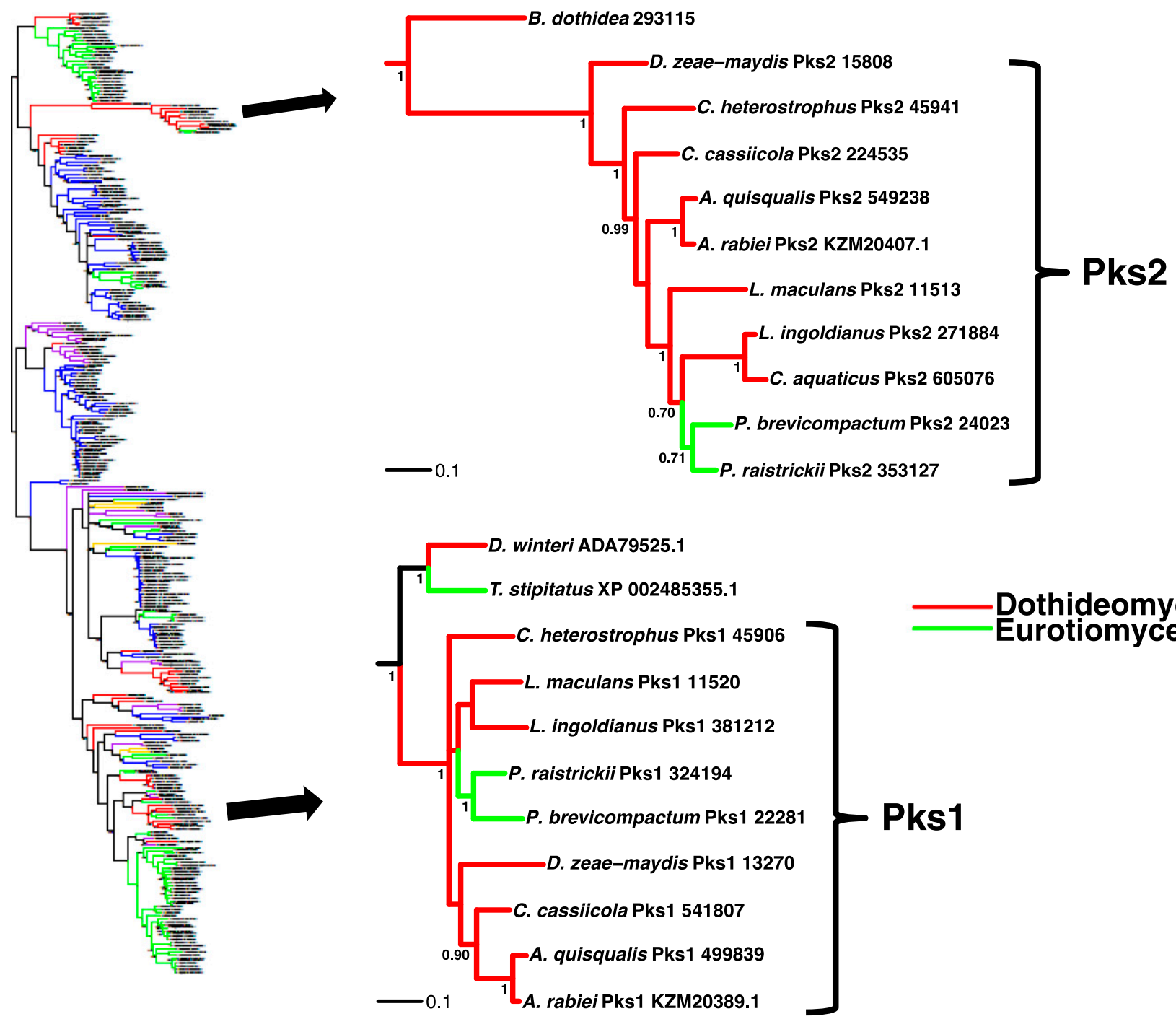

Fig. 3. Candidate Tox1 Pks1 and Pks2 orthologs group, with strong support, with Cochliobolus heterostrophus and Didymella zeae-maydis Pks1 and Pks2. A Pks1 and Pks2 comprehensive phylogenetic tree includes 323 nonredundant top blast hits using C. heterostrophus Pks1 and Pks2 KS domains against both Mycocosm and National Center for Biotechnology Information databases. C. heterostrophus Pks1 and Pks2 are in robust independent clades (each with Bayesian support of 1) that contain all putative Tox1 Pks1 and Psk2 orthologs. Note that Dothideomycetes dominate each of these clades and that the Eurotiomycete species are nested within. 


\section{Species tree}

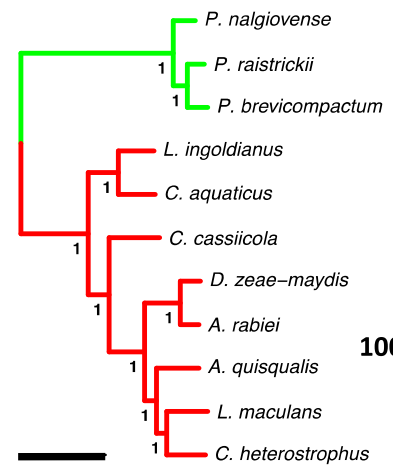

Tox1 tree

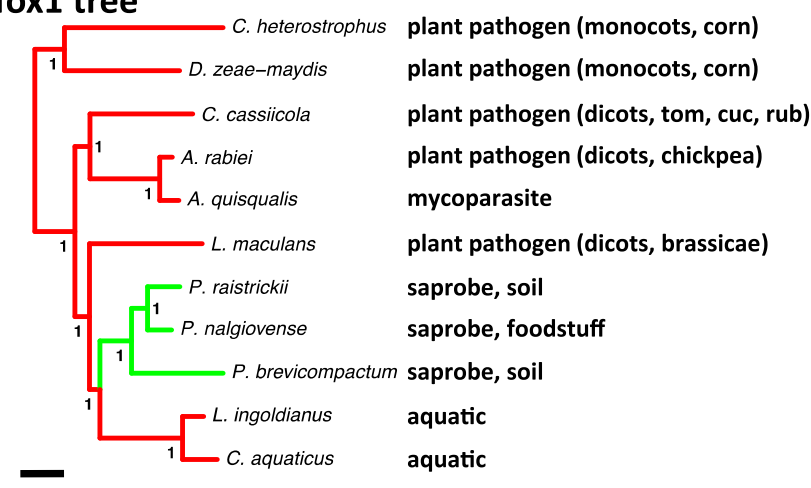

Pks1

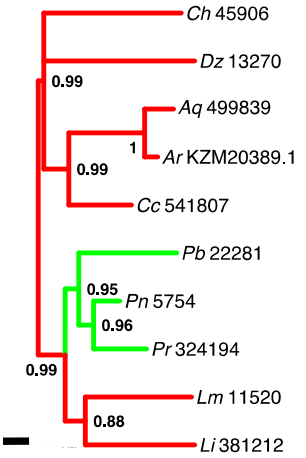

Lam1

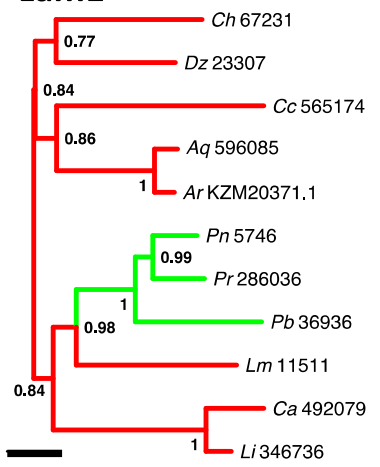

Dec1

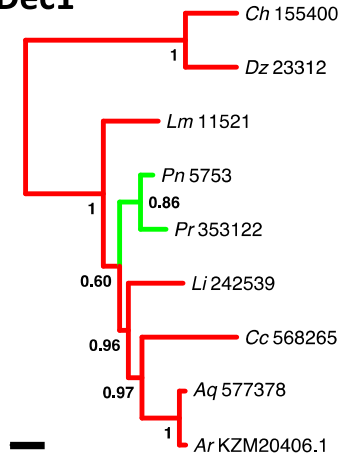

Pks2

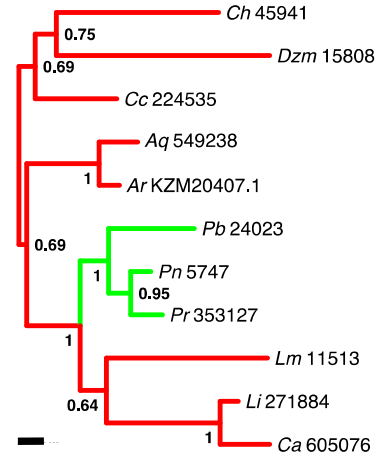

Oxi1

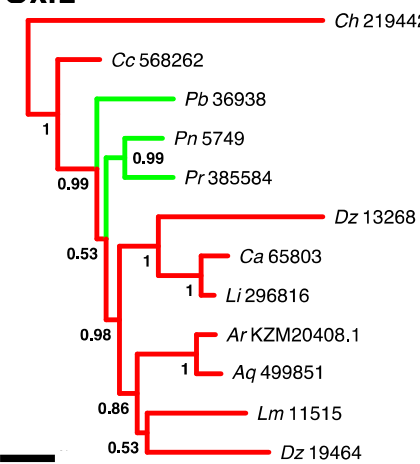

Tox10

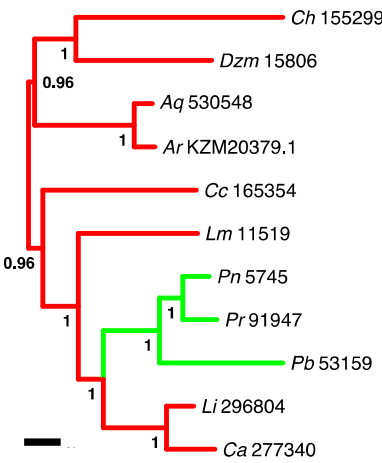

Tox9

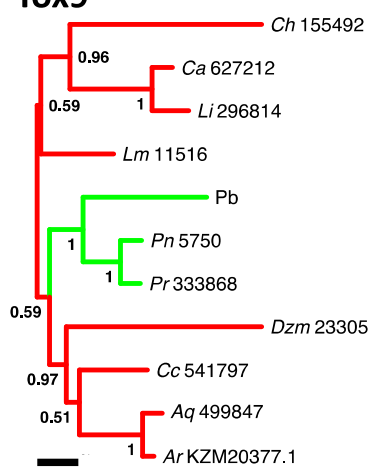

$\operatorname{Red} 2 / 3(a / b)$

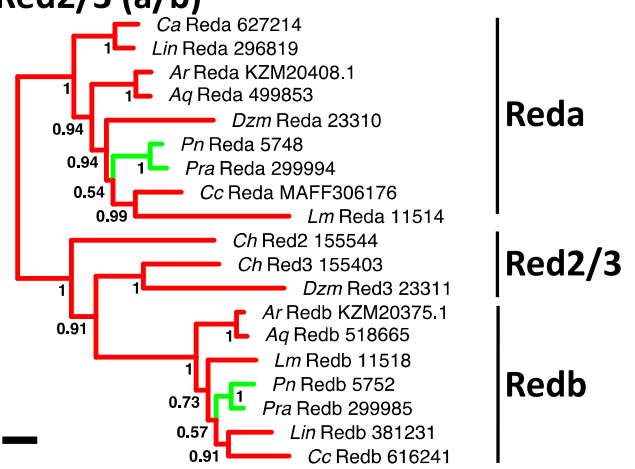

Fig. 4. Topology of Tox 1 protein trees compared with topology of species tree. Top row left, Species tree of 19 conserved protein sequences (Grandaubert et al. 2014). Numbers refer to estimates of evolutionary distance, in millions of years between taxa (Cochliobolus heterostrophus or Didymella zeae-maydis) or groups (Dothideomycetes or Eurotiomycetes). Top row right, Tree of concatenated Tox 1-associated protein sequences in each species. Environmental lifestyle is shown. Note the topology of the Tox1 tree is discordant with that of the species tree. Bottom rows, Individual Tox 1 protein trees. In most cases the individual trees have the same topology as the concatenated Tox 1 tree. In all cases, the three Eurotiomycetes are nested within Dothideomycetes. Tree is mid-point rooted with Bayesian posterior probabilities at nodes. Scale bars represent number of substitutions per site (Pks1 and Pks2 $=0.025$, all other trees $=0.1)$. Note that the topology of the small Red2/Red 3 tree differs from that of the large tree and that positions of the Reda and Redb groups are flipped, likely due to the influence of outgroups in the larger trees. $\mathrm{Aq}=$ Ampelomyces quisqualis, $\mathrm{Ar}=$ Ascochyta rabiei, $\mathrm{Ca}=$ Clohesyomyces aquaticus, $\mathrm{Cc}=$ Corynespora cassiicola, $\mathrm{Ch}=$ C. heterostrophus, $\mathrm{Dz}=$ D. zeae-maydis, $\mathrm{Li}=$ Lindgomyces ingoldianus, $\mathrm{Lm}=$ Leptosphaeria maculans, $\mathrm{Pb}=$ Penicillium brevicompactum, $\mathrm{Pn}=$ P. $n$ algiovense, $\operatorname{Pr}=P$. raistrickii. 
clearly separated Dothideomycete and Eurotiomycete clades (Fig. 4, top left).

Do Tox1 proteins of the Dothideomycete species group as expected given the species tree? For most species with Toxl or Toxl-like clusters, they do not. One exception is the two aquatic species Lindgomyces ingoldianus and Clohesyomyces aquaticus, which grouped together in Tox 1 protein and species trees. Notably, these are also the most ancient Dothideomycetes carrying Toxl-like genes that we have identified (Grandaubert et al. 2014). In contrast, Ascochyta rabiei and Ampelomyces quisqualis grouped together in Tox1 trees, although the species tree shows that the former is most closely related to D. zeae-maydis and the latter to Leptosphaeria maculans and C. heterostrophus. This and relatively high amino acid identity between their Tox1 proteins (Table 1) suggest relatively recent transfer of the cluster between the two. Unexpectedly, Leptosphaeria maculans proteins often grouped with Lindgomyces ingoldianus and Clohesyomyces aquaticus in a cluster that included the Penicillium species, although the species tree and other work (Grandaubert et al. 2014) indicate C. heterostrophus is the closest taxonomic match. Corynespora cassiicola Tox 1 proteins grouped most frequently with Ascochyta rabiei and Ampelomyces quisqualis, unlike placement in the species tree.

Do Tox 1 proteins in T- and PM-toxin-producing fungi group as expected given the species tree? As in the concatenated Tox 1 protein tree, six of nine C. heterostrophus proteins (Pks1, Pks2, Lam1, Tox10, Dec1, and Red3) grouped with taxonomically distinct $D$. zeae-maydis instead of closely related Leptosphaeria maculans (Grandaubert et al. 2014) (Fig. 4). In two cases (Oxi1, Red2) the C. heterostrophus protein was sister to the rest of the group. Of the two D. zeae-maydis Oxi proteins, Oxi1 grouped with Leptosphaeria maculans, while Oxi2, grouped with Lindgomyces ingoldianus and Clohesyomyces aquaticus. C. heterostrophus Tox9 grouped with Lindgomyces ingoldianus and Clohesyomyces aquaticus; however, D. zeaemaydis Tox 9 did not. We propose that the close association of $C$. heterostrophus and D. zeae-maydis in the Tox 1 protein trees reflects similar biological activity as toxins targeting T-cms, but we are unable, at this point, to identify the key residues or signatures in the proteins that account for this. Based on phylogenetics, the evolutionary path of $C$. heterostrophus and D. zeae-maydis Toxl remains unresolved.

\section{Do Tox1 gene and protein features reveal evolutionary history?}

Patterns of amino acid identity, $\mathrm{G}+\mathrm{C}$ content, and codon specification bias of Toxl constituents were compared with those of species tree conserved reference genes. We predicted that i) if Toxl were inherited vertically, Toxl patterns should largely mirror those of its own species reference set, ii) if Toxl were foreign to its own species, one or more parameters would differ significantly between Toxl and reference genes in that species; and iii) if Toxl were foreign to its own species, Toxl parameters would be more similar to reference gene parameters of the donor.

Pairwise comparisons of all Tox 1 proteins in all species revealed that percent amino acid identity is generally low (Table 1; Supplementary Fig. S11), thus, we can rule out an HGT event at the time of the 1970 epidemic from any of our subject taxa into C. heterostrophus or D. zeae-maydis. If this had been the case, we would expect identity between donor and recipient to be very high.

Among species carrying Toxl or Toxl-like genes, there is evidence for both horizontal and vertical transmission of Toxl (supported by statistical analyses). First, Tox1 identities between the Eurotiomycetes and the Dothideomycetes species were not significantly different, in contrast to reference protein identities, which reflect taxonomic divergence. This corroborates phylogenetic analyses that suggest the Eurotiomycetes species received the cluster from a member or members of the Dothideomycete lineage. Second, Ampelomyces quisqualis and Ascochyta rabiei had significantly higher percent identity $(90.90 \%)$ than expected, given reference gene identity, suggesting HGT between these lineages and corroborating phylogenetic analyses. Third, in contrast, high identity (84.37\%) of Tox 1 cohorts of closely related Lindgomyces ingoldianus and Clohesyomyces aquaticus, mirrors that of their reference proteins $(92.61 \%)$, in keeping with a pattern of vertical transfer from a common ancestor, as suggested by phylogenetic evidence.

Notably, Tox1 proteins of C. heterostrophus and D. zeaemaydis are not more similar to each other (58.64\%) than they are to those of the remaining species (Table 1), with two exceptions. Amino acid identities of Dec1 (74.70\%) and Red1 (70.94\%), both at Tox1B, are much higher than all other comparisons. Previously, we speculated that Dec1, a decarboxylase, removes one carbon from the polyketide backbone, rendering all T- and PM-toxin molecules odd-numbered carbon chains (Rose et al. 2002). Red1, as noted above, is unique to these two toxin-producing species. Generally low amino acid identity between $C$. heterostrophus and $D$. zeae-maydis Tox1 proteins supports our speculation that their grouping together (Fig. 4) may be a reflection of key (unknown) residues that determine overlapping biological function as HSTs targeting T-cms

Table 1. Cochliobolus heterostrophus Tox1 protein amino acid identity between indicated species ${ }^{\mathrm{a}}$

\begin{tabular}{|c|c|c|c|c|c|c|c|c|c|c|c|}
\hline Gene $^{\text {b }}$ & $C h$ & $D z$ & $A q$ & $A r$ & $\mathrm{Ca}$ & $C c$ & $L i$ & $L m$ & $P b$ & $P n$ & $P r$ \\
\hline All reference ${ }^{c}$ & - & 89.41 & 91.09 & 89.23 & 85.75 & 87.33 & 85.94 & 91.86 & 73.30 & 73.20 & 73.43 \\
\hline All Tox $1^{\mathrm{d}}$ & - & 58.64 & 53.61 & 54.04 & 53.19 & 54.19 & 52.00 & 52.50 & 55.62 & 53.47 & 53.61 \\
\hline PKS1 & - & 61.02 & 62.35 & 62.75 & 57.09 & 60.73 & 60.03 & 60.53 & 59.24 & 62.01 & 62.49 \\
\hline$P K S 2$ & - & 64.80 & 66.16 & 65.37 & 60.11 & 74.92 & 60.79 & 61.12 & 61.38 & 63.61 & 61.93 \\
\hline$D E C 1$ & - & 74.70 & 47.22 & 47.62 & - & 44.44 & 47.22 & 49.21 & - & 51.00 & 49.80 \\
\hline$L A M 1$ & - & 65.78 & 65.24 & 65.07 & 58.81 & 60.33 & 60.79 & 61.64 & 60.73 & 62.98 & 62.01 \\
\hline OXII & - & 53.49 & 55.04 & 54.26 & 53.88 & 58.91 & 53.49 & 56.59 & 56.98 & 53.94 & 55.64 \\
\hline$R E D 1$ & - & 70.94 & - & - & - & - & - & - & - & - & - \\
\hline RED2_155544 & - & 46.76 & 45.11 & 47.00 & 41.74 & 43.67 & 42.06 & 41.03 & - & 43.22 & 44.94 \\
\hline RED3_155403 & - & 51.57 & 46.13 & 45.82 & - & 44.58 & 45.25 & 44.68 & - & 46.04 & 45.99 \\
\hline ТОХ9 & - & 53.93 & 54.58 & 56.04 & 58.97 & 58.46 & 58.24 & 60.07 & 56.34 & 58.58 & 59.11 \\
\hline TOX10 & - & 43.40 & 40.69 & 42.40 & 41.70 & 41.63 & 40.17 & 37.66 & 39.07 & 39.83 & 40.55 \\
\hline
\end{tabular}

${ }^{\mathrm{a}} \mathrm{Aq}=$ Ampelomyces quisqualis, $\mathrm{Ar}=$ Ascochyta rabiei, $\mathrm{Ca}=$ Clohesyomyces aquaticus, $\mathrm{Cc}=$ Corynespora cassiicola, $\mathrm{Ch}=$ Cochliobolus heterostrophus, Dz $=$ Didymella zeae-maydis, $\mathrm{Li}=$ Lindgomyces ingoldianus, $\mathrm{Lm}=$ Leptosphaeria maculans, $\mathrm{Pb}=$ Penicillium brevicompactum, $\mathrm{Pn}=$ P. nalgiovense, $\mathrm{Pr}=$ $P$. raistrickii. A full dataset is found in Supplementary Table S2.

${ }^{\mathrm{b}}$ Gene that was the source of protein being compared. Entire Pks proteins were used. Values in bold italics are notably different values.

${ }^{\mathrm{c}}$ Average of all reference proteins. Clohesyomyces aquaticus lacks a genome hit for HSP60.

d Average of all Tox 1 proteins. 
protein Urf13. However $C$. heterostrophus race $\mathrm{T}$ acquired Toxl, the subsequent reciprocal translocation may have also created novel biochemistry (we do not know if a similar genetic event occurred in D. zeae-maydis).

$\mathrm{G}+\mathrm{C}$ content of Toxl genes was significantly lower than that of the reference genes in C. heterostrophus, D. zeae-maydis, and the Eurotiomycetes species (Fig. 5; Supplementary Table S3; Supplementary Fig. S12), suggestive of a foreign origin. Several genes contributed to this $\left(M_{i}>3.5\right)$, but there was no clear pattern. Similarly, a few Tox 1 PKSs had significantly higher $\mathrm{G}+\mathrm{C}$ content than the average of all $P K S \mathrm{~s}$ in their genomes, but there was no clear pattern. Clohesyomyces aquaticus PKSI and Lindgomyces ingoldianus and Ampelomyces quisqualis $P K S 1$ and $P K S 2$ are significantly different from other $P K S$ s. We note again that the first two of these are the oldest lineages that we have identified carrying Toxl-like genes and that we have evidence for HGT into Ampelomyces quisqualis. Finally, based on $\mathrm{G}+\mathrm{C}$ content, $C$. heterostrophus and D. zeae-maydis $P K S 1$ and $P K S 2$ are not different from other $P K S$ s in their respective genomes.

The three-way interaction of gene type $\times$ host $\times$ CUT (codon usage table) in the codon adaptation analysis (CAI) was not significant $\left(F_{(100,3102)}=0.4902, P=1.000\right)$ (Supplementary Table S4; Supplementary Fig. S13), indicating that Toxl patterns do not differ significantly from conserved genes within species, thus we cannot reject the null hypothesis that all Toxl clusters have been inherited vertically, based on this analysis. Significant two-way interactions, however, indicated that Tox 1 codon specifications in C. heterostrophus, D. zeae-maydis, and the Eurotiomycete species are more different from conserved genes than in other species. First, Toxl genes scored 3.4\% lower in Eurotiomycete CUTs than in Dothideomycete CUTs, suggesting that Toxl codon specification is less similar to Eurotiomycete than to Dothideomycete CUTs and supporting the hypothesis of one or more HGT events from a Dothideomycete to an Eurotiomycete lineage. Second, Tox 1 from C. heterostrophus, D. zeae-maydis, and the Eurotiomycete species scored the lowest CAI values when calculated across all CUTs, suggesting that Toxl codon specification in these five species is more different from CUTs evaluated in this study than the remaining Toxl clusters and supporting the hypothesis that Tox 1 and Tox 1 -like clusters in these five species are foreign in origin. These findings were also reflected in the relative synonomous codon usage (RSCU) analysis, which showed that Toxl in these species differed significantly from reference datasets (Fig. 6), providing support again for a foreign origin of Toxl in these species. RSCU analysis also suggests that Toxllike cluster in Leptosphaeria maculans differs significantly from reference datasets (Fig. 6).

Toxl gene dN/dS (nonsynonymous to synonymous nucleotide substitutions) rates were unremarkable, except that comparison of Toxl to global gene rates showed that, while PKS1 and $P K S 2$ typically had a dN/dS close to the global mean $(-1<$ $Z, 1)$, rates for other Toxl genes were generally higher, particularly for TOX10 (Supplementary Table S5; Supplementary Fig. S14). This was driven by the high relative dN/dS $(Z>2$, 98th percentile of $\mathrm{dN} / \mathrm{dS}$ ) between $C$. heterostrophus TOX10 and TOX10 in five other species. This suggests mild positive selective pressure on TOX10 in C. heterostrophus.

\section{Does Corynespora cassiicola or Leptosphaeria maculans produce a metabolite with T-toxin-like activity?}

All genes in Toxl-like clusters of Leptosphaeria maculans and Corynespora cassiicola were demonstrated to be expressed under the vegetative growth conditions described below (data not shown). In the microbial assay, $C$. heterostrophus race $\mathrm{T}$ and D. zeae-maydis positive control plugs caused large halos associated with killing of $E$. coli carrying the T-Urf13 protein, while the race $\mathrm{O}$ negative-control plugs did not (Fig. 7, left). In no case did plugs from any other isolate produce clear halos. In some cases, a diffuse halo appeared around a plug, but this proved to be nonspecific when the same strain was assayed on $E$. coli cells without the T-Urf13 protein (Fig. 7, middle). The same results were obtained when culture filtrates were assayed (not shown).

In the virulence assay, lesions were caused by $C$. heterostrophus races $\mathrm{T}$ and $\mathrm{O}$ and by $D$. zeae-maydis on both $\mathrm{T}$ and $\mathrm{N}$ cytoplasm maize, as expected (Inderbitzin et al. 2010). Chlorotic streaking indicative of T-toxin and PM-toxin produced by $C$. heterostrophus race $\mathrm{T}$ and $D$. zeae-maydis, respectively, were apparent on T-cytoplasm maize. No symptoms of any kind developed upon inoculation with Corynespora cassiicola, Leptosphaeria maculans, or Leptosphaeria biglobosa (data not shown).

A mutant of Corynespora cassiicola lacking PKS10, the ortholog of $C$. heterostrophus PKS1, showed reduced virulence on host tomato leaves, compared with the wild-type (WT) progenitor (Fig. 7, right). This combined with the microbial assay, indicates that the product of $P K S 10$ has a role in virulence but is not the functional equivalent of T-toxin.

\section{DISCUSSION}

While the genetic source of C. heterostrophus Toxl, responsible for biosynthesis of T-toxin and the subsequent SCLB epidemic, remains unclear, we have advanced understanding of Toxl evolutionary history and demystified the path by which a previously unknown, unique, secondary metabolite came to have ravaging agricultural consequences. We note that, in all cases where they are found, most Toxl or Toxl-like genes have introns and, thus, are likely of eukaryotic origin.

We have demonstrated here that i) Toxl orthologs are found in taxa other than C. heterostrophus race T, ii) Toxl orthologs group together phylogenetically, which suggests a common evolutionary origin, iii) Toxl clusters in non-HST producers are in compact linear array, which is likely the ancestral arrangement, iv) percent amino acid identity between Tox1 proteins across species is low, indicating that no extant species under study was a Toxl donor, v) Eurotiomycete orthologs group phylogenetically with Dothideomycete orthologs, suggesting the former

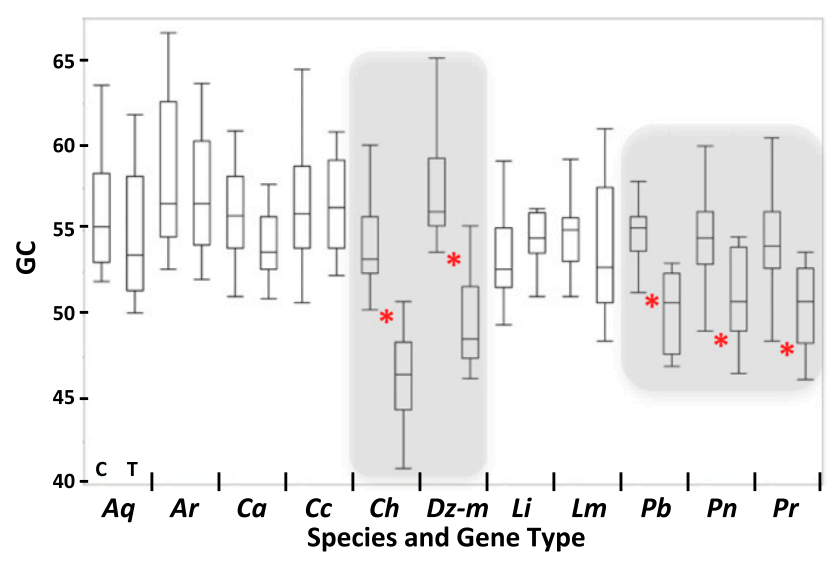

Fig. 5. Analysis of $\mathrm{G}+\mathrm{C}$ content of all species and gene types (Toxl and reference). Percent $\mathrm{G}+\mathrm{C}$ content box plots. Shaded boxes and asterisks indicate significant differences between conserved and Tox 1 gene data. Horizontal lines within the boxes represents the median value, whiskers are drawn to the furthest point within $1.5 \times$ interquartile range. Aq $=$ Ampelomyces quisqualis, $\mathrm{Ar}=$ Ascochyta rabiei, $\mathrm{Ca}=$ Clohesyomyces aquaticus, $\mathrm{Cc}=$ Corynespora cassiicola, $\mathrm{Ch}=$ Cochliobolus heterostrophus, $\mathrm{Dz}=$ Didymella zeae-maydis, $\mathrm{Li}=$ Lindgomyces ingoldianus, $\mathrm{Lm}=$ Leptosphaeria maculans, $\mathrm{Pb}=$ Penicillium brevicompactum, $\mathrm{Pn}=P$. nalgiovense, $\mathrm{Pr}=$ P. raistrickii. 


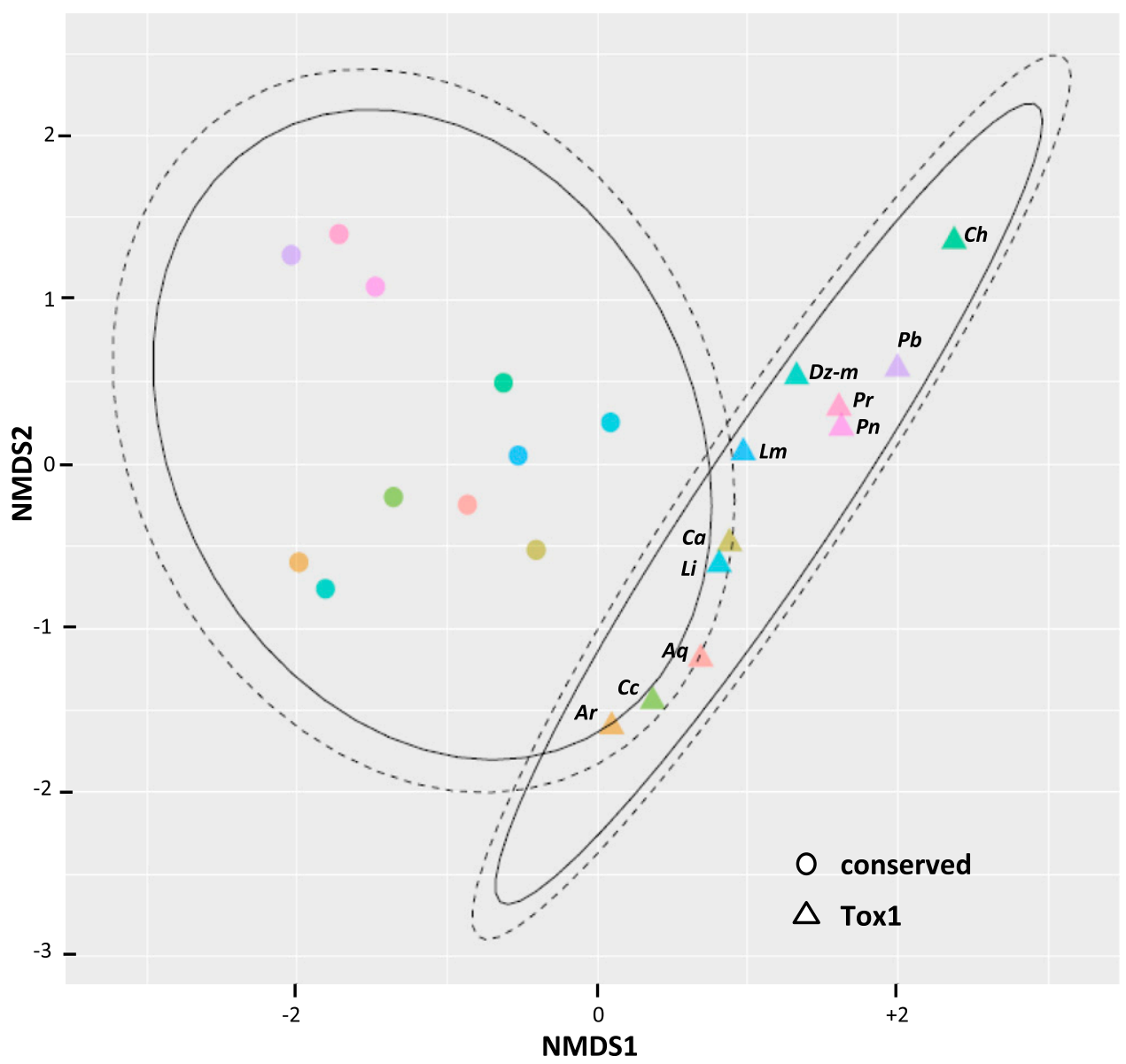

Fig. 6. Nonmetric multidimensional scaling of relative synonymous codon usage values for all species $(\mathrm{Aq}=$ Ampelomyces quisqualis, Ar $=$ Ascochyta rabiei, $\mathrm{Ca}=$ Clohesyomyces aquaticus, $\mathrm{Cc}=$ Corynespora cassiicola, $\mathrm{Ch}=$ Cochliobolus heterostrophus, $\mathrm{Dz}=$ Didymella zeae-maydis, $\mathrm{Li}=$ Lindgomyces ingoldianus, $\mathrm{Lm}=$ Leptosphaeria maculans, $\mathrm{Pb}=$ Penicillium brevicompactum, $\mathrm{Pn}=P$. nalgiovense, $\mathrm{Pr}=P$. raistrickii) and gene types (Toxl and conserved). Ovals represent confidence intervals $(90 \%)$ for each gene type, with the dotted line drawn using a normal distribution and the solid line using a $t$-distribution. Clear separation of the gene types along the primary $(x)$ axis indicates that codon usage of Toxl genes was more similar to other Toxl gene datasets than to the reference genes. However, only Toxl genes of Cochliobolus heterostrophus, D. zeae-maydis, Leptosphaeria maculans, and the Eurotiomycetes were outside of the overlapping confidence intervals (significantly different from reference genes).
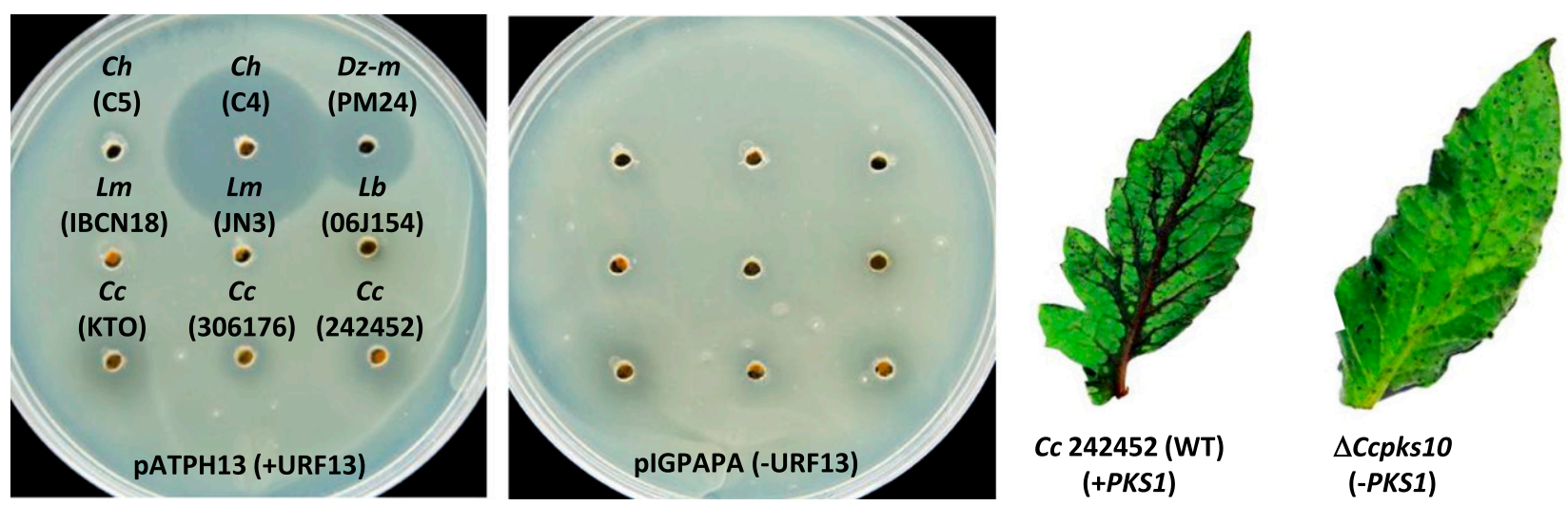

Fig. 7. Assay of strains for toxin activity and for alteration in virulence. Plates were spread with T-toxin- and PM-toxin-sensitive Escherichia coli cells and mycelial plugs to be tested were placed mycelium side down on the lawn of $E$. coli cells. Left and middle, respectively, E. coli carrying the T-toxin target protein URF13 and E. coli carrying a vector lacking URF13. Large halos are seen with the two, positive toxin-producing control strains Cochliobolus heterostrophus race $\mathrm{T}$ and Didymella zeae-maydis in the left but not the middle panel. In no case did plugs from three isolates of Corynespora cassiicola, two isolates of Leptosphaeria maculans, or the single isolate of Leptosphaeria biglobosa, a member of the Leptosphaeria complex that does not harbor PKS1 and PKS2 homologs (Grandaubert et al. 2014), produce clear halos. In some cases (e.g., Corynespora cassiicola), a diffuse halo appeared, but this proved to be nonspecific when the same strain was assayed on E. coli cells without the T-Urf13 protein. Right, tomato leaves inoculated with wild-type Corynespora cassiicola TTRC1-1 (leaf on the left) and the same strain lacking the ortholog (PKS10) of C. heterostrophus PKS1 (leaf on the right). Symptoms are reduced in the latter case. 
may have acquired Toxl from a Dothideomycete ancestor, vi) $\mathrm{RSCU}, \mathrm{G}+\mathrm{C}$ content, and CAI analyses indicate that Toxl characteristics of $C$. heterostrophus, D. zeae-maydis, and the Eurotiomycetes are significantly different from reference genes in their own genomes, which suggests a foreign origin, and vii) two genes $(A B C, O X R)$ are found only in Toxl-like clusters other than those of $C$. heterostrophus and D. zeae-maydis, possibly accounting for the lack of T-toxin-like activity and suggesting that the biological function of T-toxin and PM-toxin as HSTs is not the function of the metabolite produced by the ancestral cluster.

\section{MATERIALS AND METHODS}

\section{Genome sequences and Tox1 proteins.}

Genome sequences and protein catalogs of most strains including $C$. heterostrophus strains $\mathrm{C} 4$ (race $\mathrm{T}$ ) were acquired from JGI Mycocosm (Grigoriev et al. 2014). Ascochyta rabiei ArDII, ITCC number 4638, was acquired from GenBank (JYNV00000000.1). Two additional strains of Corynespora cassiicola (MAFF242452 [TTRC1-1, tomato] and MAFF306176 [cucumber]) were sequenced by HiSeq2000 and were assembled de novo using Velvet v1.2.08, resulting in 6,653 and 2,996 contigs in MAFF242452 (45,156,701 bp) and MAFF306176 (41,517,144 bp). D. zeae-maydis PM3018 (3018) was sequenced at the National Instrumentation Center for Environmental Management at Seoul National University, using an Illumina HiSeq 2000-based wholegenome shotgun strategy, and was de novo assembled, using the CLC Genomics Workbench ver. 5.5. Annotation was de novo, using Augustus (Stanke et al. 2006). Genome data were transferred to the Mycocosm website. C. heterostrophus Toxl proteins were retrieved from GenBank.

\section{Phylogenetics of Tox1 proteins.}

Dataset assembly. To evaluate evolutionary histories of individual Tox 1 genes, C. heterostrophus Tox 1 proteins were used to query Mycocosm and National Center for Biotechnology Information nonredundant protein databases and the top 100 blastp hits for each were retrieved. Redundant hits were removed. The ketosynthase (KS) domains were used for PKS proteins. All KS hits were trimmed to the $\mathrm{N}$ terminal 750 amino acids, were aligned with KS models (Bushley and Turgeon 2010; Condon 2013) using MAFFT version7 (Katoh and Standley 2013), and were further trimmed to signature motifs $\left(5^{\prime}: \mathrm{P}-\mathrm{I} / \mathrm{L}-\right.$ A-V/I-V/I-G; 3' (PKS1): H-A-I-L/I-E-S/N, 3' (PKS2): H-A/C-I$\mathrm{X}-\mathrm{X}-\mathrm{X}-\mathrm{A} / \mathrm{P}$ ) using Mesquite (available online). Pks1 of Clohesyomyces aquaticus (ID 277208) is truncated at the $5^{\prime}$ end, thus, the KS domain is missing. For the unhosted Corynespora cassiicola strains MAFF242452 and MAFF306176, Tox1 proteins were used to query assembled nucleotide sequence using blastx. Corynespora cassiicola Reda in CCP version1.0 (ID 628820) was truncated relative to other Reda genes; the ortholog in Corynespora cassiicola (MAFF306176, cucumber) was substituted. The genome of $P$. nalgiovense was not available when the large tree analyses were done.

To evaluate phylogenetic congruence, a species tree dataset was assembled composed of 19 conserved protein sequences (a proxy for the whole genome [Grandaubert et al. 2014]) from genomes of Toxl harboring species using Saccharomyces cerevisiae protein sequences (Saccharomyces Genome Database) as queries. HSP6O was not identified in Clohesyomyces aquaticus and was considered 'missing'. For comparison, a Tox1 tree dataset of concatenated Tox1 proteins and individual Tox1 proteins datasets were assembled.

Data preparation and phylogenetic analysis. Datasets were individually aligned using MAFFT (Katoh and Standley 2013), except that genes for all phylogenetic congruence analyses were individually aligned using MUSCLE (Edgar 2004). Alignments were trimmed with GBlocks version 0.91b (Castresana 2000), specifying the less stringent criteria. The species tree and Tox 1 tree datasets were concatenated using SequenceMatrix version 1.8 (Vaidya et al. 2011) (13,548, and 3,607 characters, respectively). Models of molecular evolution were evaluated by Bayesian information criterion, using ProtTest 3.2 (Darriba et al. 2011) for individual gene trees and PartitionFinderProtein version 1.1.1 (Lanfear et al. 2012) for the concatenated Tox1 tree. The best fit model for all evolutionary history gene datasets was $\mathrm{LG}+\mathrm{I}+\mathrm{G}$, with the exception of Tox $10(\mathrm{JTT}+\mathrm{G})$. For the phylogenetic congruence datasets, the best fit models for individual Tox1 datasets were as follows: Pks1, Oxi1, Tox9, JTT+G; Lam1, Tox10, JTT+I+G; Pks2, Dec1, LG+G; Red2/3, $\mathrm{LG}+\mathrm{I}+\mathrm{G}$. The concatenated Tox 1 dataset was partitioned as follows: subset 1: Dec1 and Reda, LG+G; subset 2: Pks1 and Pks2, LG+I+G; subset 3: Lam1, Oxi1, Red1, Redb, Tox9 and Tox10, JTT+I+G. Trees were constructed by Bayesian inference, using MrBayes version 3.2.6 (Ronquist et al. 2012). The species tree was constructed by the Bayesian model-averaging approach of rjMCMC (Huelsenbeck et al. 2004), with each conserved protein specified as an individual subset, allowing for independent estimation of model and rate multipliers for each subset. For the Tox 1 tree, the portions of invariable sites and shapes of the gamma distributions were unlinked, allowing independent estimation among subsets. Posterior probabilities were inferred using two runs of 1,000,000 generations, with $25 \%$ burn-in. Trees were visualized in $\mathrm{R}$, using the Ape package (Paradis et al. 2004).

\section{Calculation of amino acid identity, G+C content, codon adaptation index, nonmetric multidimensional scaling} (NMDS) of RSCU, and selection of Tox1-associated genes.

For $C$. heterostrophus, Toxl gene intron positions were confirmed by polymerase chain reaction (PCR), using DNA/RNA as templates and PCR primers flanking candidate introns (not shown). These, with introns and stop codons removed, were used as a reference for other taxa. Percent identity matrices for amino acid alignments for Tox 1 and the 19 reference proteins (Grandaubert et al. 2014) were generated using Clustal 2.1 (Li et al. 2015). All PKSs in each genome with Toxl or Toxl-like clusters were collected from Mycocosm (SM clusters). G+C content was calculated using a custom Python script (available on request).

Amino acid identities were analyzed by two-way analyses of variance (ANOVA) conducted within each species dataset, to evaluate the interaction between gene type (conserved vs. Toxl) and species comparison (test species). Differences in means were evaluated by Tukey's honestly significant difference (HSD) in the two-way ANOVA framework in JMPPro 11.2.0.

$\mathrm{G}+\mathrm{C}$ content of Toxl suites were compared with reference genes in each species (Toxl versus reference) by least squared (LS) means contrasts (11 contrasts) conducted within a twoway ANOVA framework in JMP. To determine whether $\mathrm{G}+\mathrm{C}$ content of Toxl PKSs differed from non-Toxl-associated PKSs, modified $z$ scores (Iglewicz and Hoaglin 1993) were calculated; those with $M_{i} \geq 3.5$ were considered outliers. Statistical tests to compare $\mathrm{G}+\mathrm{C}$ content of individual Toxl to reference genes and to Toxl clusters were conducted, using the modified $z$ score test for outlier detection, as described for PKSs.

To evaluate CAI, CUTs for each species carrying Toxl or Toxl-like clusters were generated from the 19 reference genes/proteins (Grandaubert et al. 2014), using the Countcodon program (Nakamura et al. 2000). CAI values for Toxl and reference genes were then calculated against all CUTs in a pairwise manner, using the local version of the CAIcal Server (Puigbò et al. 2008). Lineage-specific patterns were evaluated by calculating Toxl CAI averages for all species in all pairwise comparisons and comparing these to reference gene values, 
using a three-way ANOVA designed to test the three-way interaction of gene type (reference versus Toxl), species of origin (host), and test CUT (gene type $\times$ host $\times$ CUT). To investigate the significant gene type $\times$ test CUT interaction, we calculated the average difference between conserved and Tox 1 gene CAIs within Dothideomycete and Eurotiomycete CUTs and compared these means by LS means contrast with a one-way ANOVA framework. To investigate the significant gene type $\times$ host interaction, we conducted a post hoc Tukey's HSD. Third, we evaluated relative synonymous codon usage (RSCU) values for each species by gene type combination, using NMDS. RSCU values for reference and Toxl sets for each species were generated from CUT tables, using a custom Python script (available upon request), and were used to calculate a pairwise distance matrix in R, using the dist function (Euclidian method) followed by MDS (metaMDS method) with default parameters, using the Vegan package (Oksanen et al. 2015). Goodness of fit was tested using Vegan's stressplot and goodness methods. MDS plots were generated with the ggplot 2 package, with $90 \%$ confidence intervals drawn with the ' $t$ ' and 'norm' parameters (Wickham 2009). Assumptions (normality of distribution and homogeneity of variance) were verified in JMP prior to analysis.

To evaluate selection, OrthoMCL (Li et al. 2003) was used to find groups of putative orthologs among all taxa carrying Tox 1 genes, using a $50 \%$ identity cutoff. Only groups with representatives from at least two species and with only one member from each species were kept. MAFFT (Katoh and Standley 2013) was used with each group of putative orthologs to generate multiple sequence alignments from all protein sequences in the group. These were converted into multiple codon alignments using PAL2NAL (Suyama et al. 2006). Rates of dN, dS, and $\mathrm{dN} / \mathrm{dS}$ between each pair of genes in the network were estimated using the method of Yang and Nielsen (2000), using PAML. To better compare the $\mathrm{dN} / \mathrm{dS}$ rates of genes in the Tox 1 cluster with those of background orthologs, $Z$ scores were calculated. Log-transformed $\mathrm{dN} / \mathrm{dS}$ rates were used to calculate $Z$ scores, as these were approximately normally distributed between all pairs of species.

\section{T-toxin activity assessment.}

Previously, we reported that all C. heterostrophus Toxl genes are highly expressed in RNA from mycelia grown on Fries medium (Pringle and Braun 1957) in the dark (Wu et al. 2012). In separate work, quantitative PCR was used to test for expression of all genes in the Toxl-like cluster in Leptosphaeria maculans IBCN18, using RNA extracted (Wu et al. 2012) from cultures grown for 7 days on $10 \% \mathrm{~V} 8$. Transcript levels were normalized to that of actin, as described previously (Gardiner et al. 2004). Expression of all C. cassicola Toxl-like genes, including PKS10 (C. heterostrophus $P K S 1$ ), was evaluated using RNA extracted from cultures grown for 5 days on Fries medium, as above.

T-toxin activity was assayed using $E$. coli carrying the maize URF13 gene on plasmid pATH13-T (Ciuffetti et al. 1992). An E. coli strain carrying pIGPAPA (Horwitz et al. 1999) lacking T-URF 13 was used as a negative control. C. heterostrophus strains C4 (race T) and C5 (race O), D. zeae-maydis 3018, Leptosphaeria maculans strains IBCN18 and JN3 (carrying PKS13 [ortholog of C. heterostrophus PKS1] and PKS14 [PKS2] [Elliott et al. 2013]), L. biglobosa 06J154 (Leptosphaeria species complex control strain, not carrying a Toxl-like cluster), and two tomato strains of Corynespora cassiicola (MAFF242452 [TTRC-1] and KTO) plus one cucumber Corynespora cassiicola strain (MAFF306176) (Shimomoto et al. 2011) were recovered from -80 glycerol stocks. A pks10deletion mutant of Corynespora cassiicola TTRC1-1 (described below) was also assayed. Each was plated on complete medium with xylose (Leach et al. 1982) or $10 \%$ V8 medium (Leptosphaeria sp.) and grown under 12-h light and 12-h dark conditions and, also, inoculated into $100 \mathrm{ml}$ of Fries medium (Pringle and Braun 1957) and grown in still culture in the dark. Plugs, taken from 7- to 10-day-old cultures were assayed on plates spread with pATH13-T or pIGPAPA. Culture filtrates were harvested after 10 to 14 days and were used directly or after being concentrated 10 times (Condon 2013). T-cytoplasm maize cultivar W64A-T and N-cytoplasm maize cultivar W64A-N were inoculated with each strain described above as described by Inderbitzin et al. (2010).

\section{Deletion of Corynespora cassiicola PKS10 and assays for virulence and T-toxin-like activity.}

PCR products for deletion of the Corynespora cassiicola TTRC1-1 PKS10 (C. heterostrophus PKS1) were constructed using the fusion PCR method (Kuwayama et al. 2002). The 5' and $3^{\prime}$ flanking regions of the PKS1O were amplified with the primer pairs CcPKS10AF/AR (atgtacacgccatcctggaga/atcaggtcg atgctagcatcagacccaacaaatcgaccag) and CcPKS10BF/BR (atgcga gtgctaccagatgtggcgtagacaacacgtcacaa/gcaatcagacctcgacaatgc), respectively. PCR fragments were fused to neomycin phosphotransferase II gene (nptII) from plasmid pII99 (Oide et al. 2006) by fusion PCR, using KOD FX Neo polymerase (Toyobo, Osaka, Japan). Fungal transformation was performed as described previously (Takao et al. 2016). Virulence of the WT and mutant strains was assessed by inoculation of a spore suspension $\left(10^{4}\right.$ spores per milliliter) on the host tomato plant (cv. Momotaro) as described previously (Takao et al. 2016).

\section{ACKNOWLEDGMENTS}

We gratefully acknowledge the Joint Genome Institute for generation of genome sequences.

\section{LITERATURE CITED}

Arny, D. C., and Nelson, R. R. 1971. Phyllosticta maydis species nova, the incitant of Yellow leaf blight of maize. Phytopathology 61:1170-1172.

Aveskamp, M. M., de Gruyter, J., Woudenberg, J. H., Verkley, G. J., and Crous, P. W. 2010. Highlights of the Didymellaceae: A polyphasic approach to characterise Phoma and related pleosporalean genera. Stud. Mycol. 65:1-60.

Baker, S. E., Kroken, S., Inderbitzin, P., Asvarak, T., Li, B. Y., Shi, L., Yoder, O. C., and Turgeon, B. G. 2006. Two polyketide synthaseencoding genes are required for biosynthesis of the polyketide virulence factor, T-toxin, by Cochliobolus heterostrophus. Mol. Plant-Microbe Interact 19:139-149.

Bushley, K. E., Ripoll, D. R., and Turgeon, B. G. 2008. Module evolution and substrate specificity of fungal nonribosomal peptide synthetases involved in siderophore biosynthesis. BMC Evol. Biol. 8:328.

Bushley, K. E., and Turgeon, B. G. 2010. Phylogenomics reveals subfamilies of fungal nonribosomal peptide synthetases and their evolutionary relationships. BMC Evol. Biol. 10:26.

Castresana, J. 2000. Selection of conserved blocks from multiple alignments for their use in phylogenetic analysis. Mol. Biol. Evol. 17:540-552.

Chang, H. R., and Bronson, C. R. 1996. A reciprocal translocation and possible insertion(s) tightly associated with host-specific virulence in Cochliobolus heterostrophus. Genome 39:549-557.

Ciuffetti, L. M., Yoder, O. C., and Turgeon, B. G. 1992. A microbiological assay for host-specific fungal polyketide toxins. Fungal Genet. Newsl. 39:18-19.

Condon, B. 2013. Genomic and molecular genetic analyses of secondary metabolism, toxin production, and iron homeostasis in Cochliobolus heterostrophus. Page 346. Ph.D. thesis, Cornell University, Ithaca, NY, U.S.A.

Condon, B. J., Leng, Y., Wu, D., Bushley, K. E., Ohm, R. A., Otillar, R., Martin, J., Schackwitz, W., Grimwood, J., MohdZainudin, N., Xue, C., Wang, R., Manning, V. A., Dhillon, B., Tu, Z. J., Steffenson, B. J., Salamov, A., Sun, H., Lowry, S., LaButti, K., Han, J., Copeland, A., Lindquist, E., Barry, K., Schmutz, J., Baker, S. E., Ciuffetti, L. M., Grigoriev, I. V., Zhong, S., and Turgeon, B. G. 2013. Comparative 
genome structure, secondary metabolite, and effector coding capacity across Cochliobolus pathogens. PLoS Genet. 9:e1003233.

Daly, J. 1982. The host-specific toxins of Helminthosporia. Pages 215-234 in: Plant Infection: The Physiological and Biochemical Basis. Y. Asada, W. R. Bushnell, S. Ouchi, and C. P. Vance, eds. Springer-Verlag, Berlin.

Darriba, D., Taboada, G. L., Doallo, R., and Posada, D. 2011. ProtTest 3: Fast selection of best-fit models of protein evolution. Bioinformatics 27:1164-1165.

Dewey, R. E., Siedow, J. N., Timothy, D. H., and Levings, C. S., 3rd. 1988 A 13-kilodalton maize mitochondrial protein in E. coli confers sensitivity to Bipolaris maydis toxin. Science 239:293-295.

Drechsler, C. 1925. Leafspot of maize caused by Ophiobolus heterostrophus n. sp., the ascigerous stage of a Helminthosporium exhibiting bipolar germination. J. Agric. Res. 31:701-726.

Edgar, R. C. 2004. MUSCLE: Multiple sequence alignment with high accuracy and high throughput. Nucleic Acids Res. 32:1792-1797.

Elliott, C. E., Callahan, D. L., Schwenk, D., Nett, M., Hoffmeister, D., and Howlett, B. J. 2013. A gene cluster responsible for biosynthesis of phomenoic acid in the plant pathogenic fungus, Leptosphaeria maculans. Fungal Genet. Biol. 53:50-58

Gardiner, D. M., Cozijnsen, A. J., Wilson, L. M., Pedras, M. S., and Howlett, B. J. 2004. The sirodesmin biosynthetic gene cluster of the plant pathogenic fungus Leptosphaeria maculans. Mol. Microbiol. 53:1307-1318.

Grandaubert, J., Lowe, R. G., Soyer, J. L., Schoch, C. L., Van de Wouw, A. P., Fudal, I., Robbertse, B., Lapalu, N., Links, M. G., Ollivier, B., Linglin, J., Barbe, V., Mangenot, S., Cruaud, C., Borhan, H., Howlett, B. J., Balesdent, M. H., and Rouxel, T. 2014. Transposable elementassisted evolution and adaptation to host plant within the Leptosphaeria maculans-Leptosphaeria biglobosa species complex of fungal pathogens. BMC Genomics 15:891.

Grigoriev, I. V., Nikitin, R., Haridas, S., Kuo, A., Ohm, R., Otillar, R., Riley, R., Salamov, A., Zhao, X., Korzeniewski, F., Smirnova, T., Nordberg, H., Dubchak, I., and Shabalov, I. 2014. MycoCosm portal: Gearing up for 1000 fungal genomes. Nucleic Acids Res. 42 (D1):D699-D704.

Horwitz, B. A., Sharon, A., Lu, S. W., Ritter, V., Sandrock, T. M., Yoder, O. C., and Turgeon, B. G. 1999. A G protein alpha subunit from Cochliobolus heterostrophus involved in mating and appressorium formation. Fungal Genet. Biol. 26:19-32.

Huelsenbeck, J. P., Larget, B., and Alfaro, M. E. 2004. Bayesian phylogenetic model selection using reversible jump Markov chain Monte Carlo. Mol. Biol. Evol. 21:1123-1133.

Iglewicz, B., and Hoaglin, D. C. 1993. How to detect and handle outliers. ASQC Quality Press, Milwaukee, WI.

Inderbitzin, P., Asvarak, T., and Turgeon, B. G. 2010. Six new genes required for production of T-toxin, a polyketide determinant of high virulence of Cochliobolus heterostrophus to maize. Mol. Plant-Microbe Interact 23:458-472.

Katoh, K., and Standley, D. M. 2013. MAFFT multiple sequence alignment software version 7: Improvements in performance and usability. Mol. Biol. Evol. 30:772-780.

Kodama, M., Rose, M. S., Yang, G., Yun, S. H., Yoder, O. C., and Turgeon, B. G. 1999. The translocation-associated toxl locus of Cochliobolus heterostrophus is two genetic elements on two different chromosomes. Genetics 151:585-596.

Kroken, S., Glass, N. L., Taylor, J. W., Yoder, O. C., and Turgeon, B. G. 2003 Phylogenomic analysis of type I polyketide synthase genes in pathogenic and saprobic ascomycetes. Proc. Natl. Acad. Sci. U.S.A. 100:15670-15675.

Kuwayama, H., Obara, S., Morio, T., Katoh, M., Urushihara, H., Tanaka, Y., 2002. PCR-mediated generation of a gene disruption construct without the use of DNA ligase and plasmid vectors. Nucl. Acids Res. 30.

Lanfear, R., Calcott, B., Ho, S. Y., and Guindon, S. 2012. Partitionfinder: Combined selection of partitioning schemes and substitution models for phylogenetic analyses. Mol. Biol. Evol. 29:1695-1701.

Leach, J., Lang, B. R., and Yoder, O. C. 1982. Methods for selection of mutants and in vitro culture of Cochliobolus heterostrophus. J. Gen. Microbiol. 128:1719-1729.

Levings, C. S., 3rd. 1990. The Texas cytoplasm of maize: Cytoplasmic male sterility and disease susceptibility. Science 250:942-947.

Levings, C. S., 3rd. 1993. Thoughts on cytoplasmic male sterility in cms-T maize. Plant Cell 5:1285-1290.

Li, L., Stoeckert, C. J., Jr., and Roos, D. S. 2003. OrthoMCL: Identification of ortholog groups for eukaryotic genomes. Genome Res. 13:2178-2189.

Li, W., Cowley, A., Uludag, M., Gur, T., McWilliam, H., Squizzato, S., Park, Y. M., Buso, N., and Lopez, R. 2015. The EMBL-EBI bioinformatics web and programmatic tools framework. Nucleic Acids Res. 43 (W1):W580-W584.

Nakamura, Y., Gojobori, T., and Ikemura, T. 2000. Codon usage tabulated from international DNA sequence databases: Status for the year 2000. Nucleic Acids Res. 28:292.

Oide, S., Moeder, W., Krasnoff, S., Gibson, D., Haas, H., Yoshioka, K., and Turgeon, B. G. 2006. NPS6, encoding a nonribosomal peptide synthetase involved in siderophore-mediated iron metabolism, is a conserved virulence determinant of plant pathogenic ascomycetes. Plant Cell 18:2836-2853.

Oksanen, J., Blanchet F. G., Kindt, R., Legendre, P., Minchin, P. R., O'Hara, R. B., Simpson, G. L., Solymos, P., Stevens, M. H. H., and Wagner, H. H. 2015. Vegan: Community ecology package. R package vegan, vers. 2.2 1. World Agroforestry Centre, Nairobi, Kenya. Published online.

Paradis, E., Claude, J., and Strimmer, K. 2004. APE: Analyses of phylogenetics and evolution in R language. Bioinformatics 20:289-290.

Pringle, R. B., and Braun, A. C. 1957. The isolation of the toxin of Helminthosporium victoriae. Phytopathology 47:369-371.

Puigbò, P., Bravo, I. G., and Garcia-Vallve, S. 2008. CAIcal: A combined set of tools to assess codon usage adaptation. Biol. Direct 3:38.

Ronquist, F., Teslenko, M., van der Mark, P., Ayres, D. L., Darling, A., Höhna, S., Larget, B., Liu, L., Suchard, M. A., and Huelsenbeck, J. P 2012. MrBayes 3.2: Efficient Bayesian phylogenetic inference and model choice across a large model space. Syst. Biol. 61:539-542.

Rose, M. S., Yun, S. H., Asvarak, T., Lu, S. W., Yoder, O. C., and Turgeon, B. G. 2002. A decarboxylase encoded at the Cochliobolus heterostrophus translocation-associated Tox $1 B$ locus is required for polyketide (T-toxin) biosynthesis and high virulence on T-cytoplasm maize. Mol. PlantMicrobe Interact 15:883-893.

Shimomoto, Y., Sato, T., Hojo, H., Morita, Y., Takeuchi, S., Mizumoto, H. Kiba, A., and Hikichi, Y. 2011. Pathogenic and genetic variation among isolates of Corynespora cassiicola in Japan. Plant Pathol. 60:253-260.

Stanke, M., Schöffmann, O., Morgenstern, B., and Waack, S. 2006. Gene prediction in eukaryotes with a generalized hidden Markov model that uses hints from external sources. BMC Bioinformatics 7:62.

Suyama, M., Torrents, D., and Bork, P. 2006. PAL2NAL: Robust conversion of protein sequence alignments into the corresponding codon alignments. Nucleic Acids Res. 34 (Web Server):W609-W612.

Takao, K., Akagi, Y., Tsuge, T., and Kodama, M. 2016. Functional characterization of putative $\mathrm{G}$ protein-coupled receptors in the tomato pathotype of Alternaria alternata. J. Gen. Plant Pathol. 82:82-88.

Turgeon, B. G., and Baker, S. E. 2007. Genetic and genomic dissection of the Cochliobolus heterostrophus Toxl locus controlling biosynthesis of the polyketide virulence factor T-toxin. Adv. Genet. 57:219-261.

Turgeon, B. G., and Lu, S.-W. 2000. Evolution of host specific virulence in Cochliobolus heterostrophus. Pages 93-126 in: Kronstad, JW. F. Pathology, ed. Kluwer, Dordrecht, The Netherlands.

Tzeng, T. H. 1990. A restriction fragment length polymorphism map of Cochliobolus heterostrophus. Ph. D. Thesis, Iowa State University, Ames, IA, U.S.A.

Tzeng, T. H., Lyngholm, L. K., Ford, C. F., and Bronson, C. R. 1992. A restriction fragment length polymorphism map and electrophoretic karyotype of the fungal maize pathogen Cochliobolus heterostrophus. Genetics 130:81-96.

Vaidya, G., Lohman, D. J., and Meier, R. 2011. SequenceMatrix: Concatenation software for the fast assembly of multi-gene datasets with character set and codon information. Cladistics 27:171-180.

Wickham, H. 2009. Elegant Graphics for Data Analysis. Springer-Verlag, New York.

Wu, D., Oide, S., Zhang, N., Choi, M. Y., and Turgeon, B. G. 2012. ChLae1 and ChVel1 regulate T-toxin production, virulence, oxidative stress response, and development of the maize pathogen Cochliobolus heterostrophus. PLoS Pathog. 8:e1002542.

Yang, G., Rose, M. S., Turgeon, B. G., and Yoder, O. C. 1996. A polyketide synthase is required for fungal virulence and production of the polyketide T-toxin. Plant Cell 8:2139-2150.

Yang, G., Turgeon, B. G., and Yoder, O. C. 1994. Toxin-deficient mutants from a toxin-sensitive transformant of Cochliobolus heterostrophus. Genetics 137:751-757.

Yang, Z., Nielsen, R., Goldman, N., and Pedersen, A. M. 2000. Codonsubstitution models for heterogeneous selection pressure at amino acid sites. Genetics 155:431-449.

Yoder, O., and Mukunya, D. 1972. A host-specific toxic metabolite produced by Phyllosticta maydis. Phytopathology 62:799.

Yun, S. H. 1998. Molecular genetics and manipulation of pathogenicity and mating determinants in Cochliobolus heterostrophus and Mycosphaerella zeae-maydis. Ph.D. thesis. Cornell University, Ithaca, NY, U.S.A.

Yun, S. H., Turgeon, B. G., and Yoder, O. C. 1998. REMI-induced mutants of Mycosphaerella zeae-maydis lacking the polyketide PM-toxin are deficient in pathogenesis to corn. Physiol. Mol. Plant Pathol. 52:53-66.

\section{AUTHOR-RECOMMENDED INTERNET RESOURCES}

Mesquite: http://www.mesquiteproject.org

Mycocosm: https://genome.jgi.doe.gov/programs/fungi/index.jsf

Saccharomyces Genome Database: https://www.yeastgenome.org 